\title{
Ethical Indian Education System- A Need of the Nation
}

\author{
Shelly Bhagat ${ }^{1 *}$
}

\section{ABSTRACT}

The ancient Education system of India, was very much prosperous, value-based and skill focused which further developed the teaching abilities and the intellectual level along with the knowledge of cultural heritage, awareness of responsibility towards nation, and more or less the number of the students participating towards learning. The base of present Indian education system was adopted by Indians from Britishers and the British given Economy system, Judicial system, Administrative System and Parliamentary system of India, is well taken care of by us. The emerging and so called developed phenomenon of corruption has not even spared this value system of learning. In this paper the major areas which are to be focused upon for the improvement and growth of Indian education system by the society to cure and maintain the purity of education in itself is discussed.

Keywords: Ethics and values of Indian Education System, Teaching, Education, learning, Psychological challenges.

The most fundamental element of how we perceive the education lies in the distinction often made in academic and policy discourse between the "instrumental" and the "intrinsic" value of education ( Dreze and Sen, 1996).

The core vision for education is distracted and hence the nation is losing the sight of broader and useful vision in the rush to find "solutions". The sight of the purpose of education is further lost and it is only being driven by the concerns of multiplying the economy, instead. Making a life better to live should be the aim of Education, not only through the economic upliftment but also through moral, social and spiritual strengthening and awakening. Ethics is a branch of philosophy that deals with the morality; the word ethic has been derived from the Greek word 'ethos' which means 'character' (Paula, 2011). To determine what is good for the individual and for the society, Aristotle said, it is necessary to posses three virtues of practical wisdom: temperance, courage and justice (Paula, 2011). Values which are the guiding principle of life, contribute to the all round development of an individual. Values also add a good quality to the life and it should also contribute to the welfare of family, the community and the nation itself

\footnotetext{
${ }^{1}$ Research Scholar, Department of psychology, Panjab University, Chandigarh

*Responding Author

(C) 2016 I S Bhagat; licensee IJIP. This is an Open Access Research distributed under the terms of the Creative Commons Attribution License (http://creativecommons.org/licenses/by/2.0), which permits unrestricted use, distribution, and reproduction in any Medium, provided the original work is properly cited.
} 
(Pattaya, 2011). Education is instrumental in 'nation buliding', through preparation of children for the roles they will play in the future develop of the country.

\section{AREAS TO BE FOCUSED UPON:-}

Gender Equality : Gender is embedded with a complex social and institutional structure in India, and It is therfore important to understand the intermeshing of poverty, social inequalities and gender relations. Meaningful access needs to happen at every single step of the education delivery system, right from bringing the child to the school or for that matter, taking the school to child. Right from ensuring that schools are available for all children from any social group to ensure that once the child reaches the school, it is a safe heaven of learning and growth to achieve his or her potential instead of a few skills thrown in a staccato manner.

Content of learning : The goal of quality instructions is more often idealized than realised, as teachers struggle to provide effective instructions. To meet the varied learning needs of students in a classroom, methods that focus on differentiating instruction must have away from a single prescribed lesson and provide teachers with the flexibility to adjust factors such as learning objectives and pace of instruction.

Process of teaching and learning : Utilising this strategy requires the teacher to provide all students with a series of relevant experiences, providing support to analyse rules and principles through discovery learning. Keeping this in mind, the National Council of Education, Research and Training (NCERT) has recently developed exemplar material on curricular adaptations, inclusive teaching and how to adopt flexibility in evaluation for children with disabilities in the classroom. The material is based on an approach whereby the teacher provides meaningful learning experiences to all children in the class and uses simple language and expression that values all children. The material comprises of a number of examples that demonstrate how to change the current teaching practices in classrooms, and support students to become independent learners and actively participate in the learning process. 1.58 lakes mainstream teachers under Sarva Sikhsha Abhiyan have already been trained on this exemplar material.

Learning for the Marginalised, SCs \& STs : while in some respects, these groups have achieved some educational advancement, they lag behind in certain other respects which continue to keep them on the margins of the educational, developmental and social mobility processes, thus leaving much to be desired to make members of these castes and tribes as equal members of hitherto unequal Indian society. One area where these groups have shown tremendous progress is in terms of enrollments at the level of education. In primary education, at the first standard of entry into structured and formal education, the enrollments match the most privileged, but by the time they arrive at standard five, their numbers seem to dwindle. For example, the Government of India Report on 'Education for All: Towards Quality and Equity', published by National University of Educational Planning and Administration (NUEPA) in 2014 documents that between 2000-01 and 2013-14, the enrolment of SC children in primary 
education increased from 21.3 million to 26.3 million, marking an increase of 24.1 percent in just one decade. Similarly, the enrolment of ST children in primary education during the same decade has increased from 11million to 14.7 million, registering 33.6 percent of increase. At the upper primary level too, both SCs and STs have registered a significant progress (from 6.7 million to 12.9 million in the case of SCs and from 3.1 million to 6.5 million in the case of STs) during 2000-01 to 2013-14.

Vocational Education in India : Government of India has launched the National Skill Development Mission on 15th July, 2015 which coincide with the World Youth Skills Day. The mission has been set up to deliver the Skill India campaign and will create convergence across sectors and states on skill training activities. As of now, the country has 249 training partners, 3222 training centres, 55,70,476 trainees, with 23,88,009 placements so far. While there are many schemes and missions under different ministries like the 'Deen Dayal Antyodaya Yojana' (skill training for urban and rural poor), 'The Digital India' and 'Make in India' campaigns are all steps to encourage skills developments to develop products within India by Indians.

Digital India : the digital India initiative, under pillar 5, Electronic Delivery of Services, the thrust areas is to include 'Massive Online Open Courses (MOOCs)' that shall be developed and leveraged for e-education by Minister of Human Resource Development (MHRD). Government of India is emphasizing on the use of Information and Communication Technology (ICT) for education in a big way. Ministry of HRD, has accordingly embarked on a major and new initiative called 'Study Webs of Active Learning for Young Aspiring Minds' (SWAYAM), which will provide one integrated platform and portal for online courses, using information and communication technology (ICT) and covering all higher education subjects and skill sector courses to ensure that the every student in our country has access to the best quality higher education at an affordable cost.

Psychological Challenges: Majority of the public schools has no counsellos or a social worker, yet schools are being asked to deal with more and more mental health needs of their students. In addition, reports of increased bullying and school violence require a recognition and response to the psychic agony of the school campus. In the last decade, mental health in schools has expanded to address school violence sexual harassment, bullying, substance abuse, discrimination and healthy discipline. Modem school consultation focuses more on early identification and intervention at the individual and systems level to help attain immediate educational and behavioural goals and to prevent long term negative outcomes in the overall personality of children. According to ICMR study (2005), the overall prevalence of child and adolescent mental health disorders is $12-14$ per cent.

Politics in Education : There was a time when an entire generation of dedicated teachers was presents in India, who was motivated by ideals and principles that were embedded in the social value system. The number of such teachers has substantially declined. Political interference is 
considered one of the most important causes for the declining ethical values in education system of India. The policy relating to recruitment, promotion and transfer of teachers in the education system are yet not formed in many states and thus the human resource management in education is not well organized in India. The political interference is largely responsible for misuse of human resource management in education. Political parties often use many teachers as their party workers and these teachers also participate willingly in politics. Those teachers who are very close to political leaders have records of misconduct and unethical behavior such as irregularity in class teaching, becoming absent from the school without taking leave. Political leaders, highlevel bureaucrats and members of the teacher unions also attempt to influence decision-making regarding the recruitment and transfer of teachers. Favoritism, nepotism and bribes are major types of misconduct in teacher's appointment, posting and transfer. So the moral and ethical commitment of teachers has gradually decreased over the years due to political interference (Nuland and Khandelwal, 2001).

Unvaluable Syllabi : In ancient India, the Vedas, the Upanishads, the epics manifested and upheld the values of Indian society. Imparting value education was the main aim of the teachers of the ancient age (Pathania, 2011). The family system in India has a long tradition right from the ancient practice of the Gurukul system. In the ancient time people lived in compound families and elder taught stories to child at home that develops moral values and after that in Gurukul they also primarily taught value education. Therefore, ancient time value education begins at home and it has continued in schools. However, with modern developments and a fast changing role of the parents, it has not been very easy for the parents to impart relevant values in their wards. Today people mostly live in nuclear families and parents are involved in their jobs and they cannot sprout values at home. Present School curriculum lack emphasize on value education. At present value education is not started at home nor taught at schools in India. Although value education is included in the primary education curriculum but at the adolescent or adult stage, which are the most sensitive stages to build the character of the youth, the curriculum finds no space to value education. However the present curriculum makes them perfect money makers, the best politicians, the well- known doctors, the skillful engineers, the greatest musicians, the marvelous actors but fails to make then realize a bit to their identity as human beings (Bala Harish, 2011).

Non- seriousness of teachers : Teachers are the role models of students and in most rural communities, they are the most educated and103respected personality. Teachers are the spreader of knowledge who helps developing pupils' understanding, attitudes, skills, learning, and core values (Patrinos and Ruthkagia, 2007). While simultaneously those teachers are mostly absent from classes providing negative role models for students. Education is now in the grasp of corruption because of high rate of teacher absenteeism. The UNESCO's International Institute of Educational Planning study on corruption in education state that there is $25 \%$ teacher absenteeism in India which is among the highest in the world. In Bihar two of every five teachers were reported absent, the figure in UP was reported to be one-third of the total teachers. Ghost 
Teacher does not just affect quality of education but it is also a huge drain on resources resulting in the wastage of $22.5 \%$ of education funds of India (Hallak, and Poisson, 2005). Teacher absenteeism is one of the most serious causes of ethical declining of education. It greatly reduces the overall effectiveness of the school, diminishes pupils' achievements, damages the school's reputation, and induces pupil absenteeism (Bray, 2003).104

\section{DISCUSSION:}

Indian education system is not withstands to provide the knowledge to the students but encourages the values which are to be inculcated within an individual to make a balanced life which will eventually leads to a successful life. Knowledge is though provided by the teachers by affecting the students in a meaningful and compassionate form to make them idealise what they actually study. We have to create new and effective methods which will ensure the quality of the education in our country to further improve the world in itself. The areas discussed above should be well taken care of by the society, to maintain the progress and growth towards the ethical and valuable Indian education system. The changes we bring towards the education system will eventually describe the nation's developmental goals and objectives.

\section{REFERENCES:}

Education: Key to Success: Yojana, (special issue), January,2016.

Harry Anthony Patrinos and Ruthkagia (2007): Maximizing the Performance of Education Systems The Case of Teacher Absenteeism published in The Many Faces of Corruption, 63-87.

Kanchan Garg and Kamaljeet Kaur (2012): Declining of Ethical Standard in Higher Education System in India presented in Cambridge Business \& Economics Conference, Cambridge, UK.

MS Pabla (2011): The Corrosion of Ethics in Higher Education: A Challenge of 21st Century, International journal of management and business studies, Vol. 1(2).

Ritimoni Bordoloi (2011): Challenges in Elementary Education in India: Various Approaches, Journal of Education and Practice, Vol 2, No 7 pp 39-45 www.iiste.org.

Sailaja B (2001): value education in Time of India date Nov 18, 2001.

Shelly and Kusum Jan (2012) :Declining Ethical Values in Indian Education System, Journal of Education and Practice, Vol 3, No 12.

Srinath, S., Grimaldi, S.C., Gururaj, G., Sheshadari, S., Subbakrishna, D.K., Bhola, P., Kumar, N. (2005). Epidemiological study of child \& adolescent psychiatric disorders in urban \& rural areas of Bangladesh, Indian Journal of Medicine and Research, 122, July, 2005, pp67-69. 